\title{
Synthesis, Characterization and Kinetic Study of poly(vinyl acetate)-g-Chitosan and its Use in Removal of Cadmium (II) ions from Water
}

\author{
Ali Jasim Hammood*, Salam A. H. Al-Ameri and Zyad H. Jawad Al-Qaisi** \\ Department of Chemistry, College of Science, Mustansiriyah University, Baghdad-Iraq. \\ *Corresponding Author: ali.jasim255@yahoo.com. \\ **Corresponding Author: zyadalqaisi@uomustansiriyah.edu.iq.
}

\begin{abstract}
The grafted vinyl acetate copolymerization lying on chitosan in weak acidic aqueous solution was examined via using $\mathrm{K}_{2} \mathrm{~S}_{2} \mathrm{O}_{8}$ as initiator. FTIR spectra, DSC, DTG and TGA were used for graft polymer characterizing. The monomer to chitosan ratio was tested and the optimal grafting conditions were affixed. the highest grafting percentage PG of production polymers have been applied to remove $\mathrm{Cd}(\mathrm{II})$ ions from water samples through adsorption experiments at $\mathrm{pH}=7$. The amounts of adsorbed metal ion on the polymers was estimated using atomic absorption spectrophotometer. The temperature effect on $\mathrm{Cd}(\mathrm{II})$ adsorption was studied too. Langmuir and Freundlich isotherms as well as kinetic study equations were employed to fit the experimental data. The results of the adsorption equilibrium for $\mathrm{Cd}(\mathrm{II})$ fitted well to Langmuir isotherm and the removal percentage at $30^{\circ} \mathrm{C}$ after $5 \mathrm{~min}$ is $76.65 \%$ and the thermodynamic parameters for the adsorption are $\Delta \mathrm{H}=96.87 \mathrm{~kJ} / \mathrm{mol} \Delta \mathrm{S}=339.19 \mathrm{~J} / \mathrm{mol} \mathrm{K}$ and $\Delta \mathrm{G}=-5.11,-11.13$ and $-11.78 \mathrm{~kJ} / \mathrm{mol}$ in different temperatures. The kinetic study of these adsorption isotherms showed that all these isotherms correlates well with the second order equation.
\end{abstract}

[DOI: 10.22401/ANJS.22.2.01]

Keywords: Adsorption, Chitosan, Graft Copolymerization, Kinetics, Water treatment.

\section{1-Introduction}

Chitosan is a nontoxic, semicrystalline, biodegradable, and biocompatible linear polysaccharide of arbitrarily connected $\beta$ $(1 \rightarrow 4)$ linked D-glucosamine de-acetylated units also $\mathrm{N}$-acetyl D-glucosamine, acetylated units which signify as homo-polymer [1-4]. The wonderful chemical, biological as well as pharmaceutical chitosan uses have concerned notice to the achievable value of chitosangrafted polymers in diverse fields such drug delivered system [5], hydrogel formation [6], and wastewater treatment [7]. So chitosan has possible uses variety as of biomedicine also pharmacy to water treatment.

Chitosan is a weak base and easy bioadsorber with a very good gel formation capacity, and it has together reactive hydroxyl and amino groups that were applied to modify its chemical characteristics [8].

Adsorption is a specific interactions between an adsorbent like a component to be adsorbed on the adsorbate surface $[9,10]$. These interactions are highly related to the chemical structure of chitosan or its functional, which are able to make interactions through hydroxyl and amine groups are tending to be ionized, as a function of $\mathrm{pH}$ ( $\mathrm{pKa}$ in the range 6.0-6.7). In that case, the chitosan amine group in will be active as a poly-cationic and bind with electrostatic interactions or ion exchange. In addition, when the amine groups are non-ionized, nitrogen atoms which have a free electron pair tend to interact with cations as an electrons poor species. It may be interact with hydrophilic, charge anionic or cationic and natural species, the baisic structural factors in the acetylation degree [11] a definite amiphilic character owing to the acetyl groups presence has been mention [12] addition the interaction possibility with species presenting a little hydrophobic nature.

This work aims to study and reports the adjustment of chitosan via grafted vinyl acetate monomer and investigate the effects of monomer ratio to chitosan. TGA, DTGA \& DSC thermal analyses and FTIR were applied for the identification of polymers synthesis. Although, the adsorption of $\mathrm{Cd}(\mathrm{II})$ ions on synthetic polymer has been examined characterization of prepared polymers. Also the adsorption of $\mathrm{Cd}(\mathrm{II})$ onto prepared polymer via batches experiments at several contact time and temperature at $\mathrm{pH}=7$ buffer solution. The 
total ion adsorbed on the new synthetic polymers was estimated via atomic absorption spectrophotometer.

\section{2-Experimental}

\subsection{Materials}

All reagents as well as compounds were locally obtained also used without any purification. Solvent used in this work were distilled from the appropriate drying agent immediately prior to use.

\subsection{Measurements}

FTIR spectroscopy for Polymers were obtained using Shimadzu 8400S FTIR in a wave number ranged between (4000$\left.800 \mathrm{~cm}^{-1}\right)$. TGA, DTG \& DSC for polymers thermal analyses were achieved at R.T. under argon inert conditions; flow rate $10 \mathrm{~mL} / \mathrm{min}$, heating rate $=5^{\circ} \mathrm{C} / \mathrm{min}$ using Linseis STA PT-1000. Atomic absorption spectrophotometer. data were completed with Phoenix-986 AA spectrophotometer. Samples were shaken and thermostated using BS-11 thermostated shaker.

\subsection{General Synthetic procedure}

\subsubsection{Graft Chitosan copolymerization by vinyl acetate:}

Grafting reaction was completed in $250 \mathrm{ml}$ round bottle flask by dissolving $1 \mathrm{~g}$ chitosan in $60 \mathrm{ml}$ of $2 \%$ acetic acid with overnight stirring at R.T. followed by reflex to $70^{\circ} \mathrm{C}$ then $0.135 \mathrm{~g}, 0.5 \mathrm{mmol}$ of potassium persulfate was added after $15 \mathrm{~min}$, diverse amounts of monomers was adding to the mixture for 180min. The mixture was treated with methanol to precipitate the polymer then washed with methanol too followed by drying under vacuum oven. The dried polymers were extracted using 40:60 methanol: water mixture for $24 \mathrm{hrs}$ to remove the homo vinyl acetate polymer.

\subsection{Adsorption study}

\subsubsection{Adsorption of cadmium(II) ions on the vinyl acetate grafted Chitosan:}

Cadmium (II) adsorption on grafted chitosan polymer resin was examined using batches method. $0.1 \mathrm{~g}$ of each dry grafted polymers was placed in $15 \mathrm{ml}$ of $\mathrm{pH}=7$ phosphate buffer solution (potassium dihydrogen phosphate and sodium hydroxide) for about $1 \mathrm{hr}$ with continuous shaking until equilibrate.

An accurate $15 \mathrm{ml}$ of standard Cd solution (400, 300, 200 and $100 \mathrm{mg} / \mathrm{L})$. The mixture was shaken at $30{ }^{\circ} \mathrm{C}$ for precise time. Each sample was filtered and the total $\mathrm{Cd}(\mathrm{II})$ ions remain in the solution was estimated via AAS at $\lambda 228.8 \mathrm{~nm}$ using $\mathrm{Cd}$ (II) ions standard curve. The temperature effect on the $\mathrm{Cd}(\mathrm{II})$ adsorption was examined by repeating the procedure again at 40 and $50{ }^{\circ} \mathrm{C}$ temperatures [13].

\section{3-Result and discussions}

3.1. Synthesis of Chitosan grafted vinyl acetate

A grafted copolymer is a series of macromolecular chain with one or more block connected to the main chain as side chain(s) [14]. Chitosan was grafted by vinyl acetate in aqueous weak acidic solution by applied $\mathrm{K}_{2} \mathrm{~S}_{2} \mathrm{O}_{8}$ as initiator.

Synthetic route for the preparation of chitosan grafted vinyl acetate polymer was shown in Scheme (1).

\subsection{Polymerization parameters effects on percentage of grafting of Chitosan graft polymer}

\subsubsection{The monomer concentration}

The monomer concentration effect on the vinyl acetate grafting on chitosan was tested, then the grafting percentage was determinated as follows:

$$
\mathrm{PG}=\frac{\mathrm{W}_{\mathrm{P}}}{W_{A}} \times 100
$$

Where PG: is the grafting percentage \%, $\mathrm{W}_{\mathrm{P}}$ is the weight of polymer result, $\mathrm{W}_{\mathrm{A}}$ is the vinyl acetate weight. The grafting percentage (PG) was established on the monomer amount to chitosan and found $=16.19 \%, 33.73 \%$ and $47.39 \%$ which are represented in Fig.(1). 


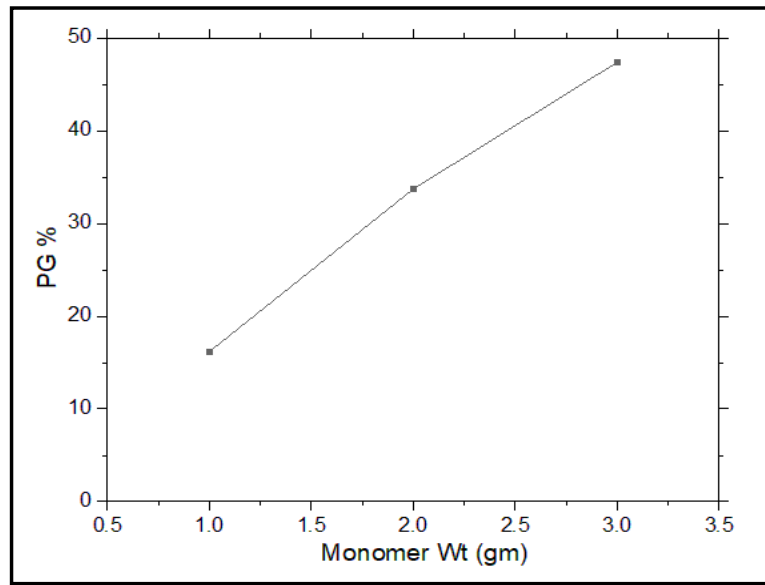

Fig.(1): Effect of monomer on percentage grafting \% of grafted copolymer; Chitosan=1g, PPS $=0.3 \mathrm{mmol}, t=180 \mathrm{~min}$, $\mathrm{T}=70^{\circ} \mathrm{C}$.

\subsection{Characterization of Chitosan grafted vinyl acetate:}

FTIR, TGA, DTG and DSC thermal analyses were applied for the identification of synthetic graft copolymer. FTIR spectrum, of graft copolymer, Fig.(2) illustrate typical band at $1732.13 \mathrm{~cm}^{-1}$, which allocate to the carbonyl ester group vibrational stretching in grafted chain. This band was sited at $1757.21 \mathrm{~cm}^{-1}$ in the spectrum of vinyl acetate monomer Fig.(3). This lower frequency shifting is owing to inter and/or intra molecular interactions through hydrogen bonding. Naturally the insolubility of graft polymer in spite of containing a large number of ester groups is produced by the crosslinking [15], 1556.61-1573.97 $\mathrm{cm}^{-1}$ due to $\left(\mathrm{COO}^{-}\right)$vibrations of free acetic acid. Further details of the other bands and their assignment are summarized in Table (1).

The DSC thermogram, Fig.(4) showed two endothermic peaks at $83.3^{\circ} \mathrm{C}$ and $237.8^{\circ} \mathrm{C}$ are due to the evaporation of adsorbed and bound water [16] as well as the temperature glass transition $\left(\mathrm{T}_{\mathrm{g}}\right)$ respectively, furthermore one exothermic peak of chitosan at $293.6{ }^{\circ} \mathrm{C}$, which may matched to the polysaccharide decomposition [17].

While, poly(vinyl acetate)-g-chitosan DSC curve, Fig.(5) showed an endothermic peak at $87.6^{\circ} \mathrm{C}$ correlated to the adsorbed also bound water evaporation in the polymer with another endothermic peak at $243.7^{\circ} \mathrm{C}$ related to the glass transition grafted copolymer temperature $\left(\mathrm{T}_{\mathrm{g}}\right)$ Furthermore, two endothermic also exothermic peaks at $307.7^{\circ} \mathrm{C}$ and $339.4^{\circ} \mathrm{C}$ may due to grafted copolymer decomposition. Whereas, two endothermic also exothermic peaks at $426.8^{\circ} \mathrm{C}$ and $490.2^{\circ} \mathrm{C}$ respectively, may due to the decomposition of poly vinyl acetate chains grafted to chitosan, these peaks are powerful signify about the grafted formation.

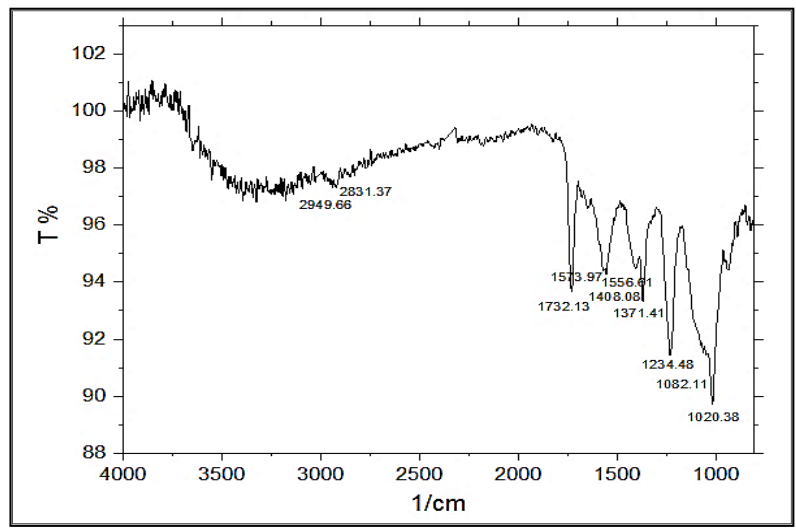

Fig.(2): FTIR spectrum of poly (vinyl acetate)-g-Chitosan.

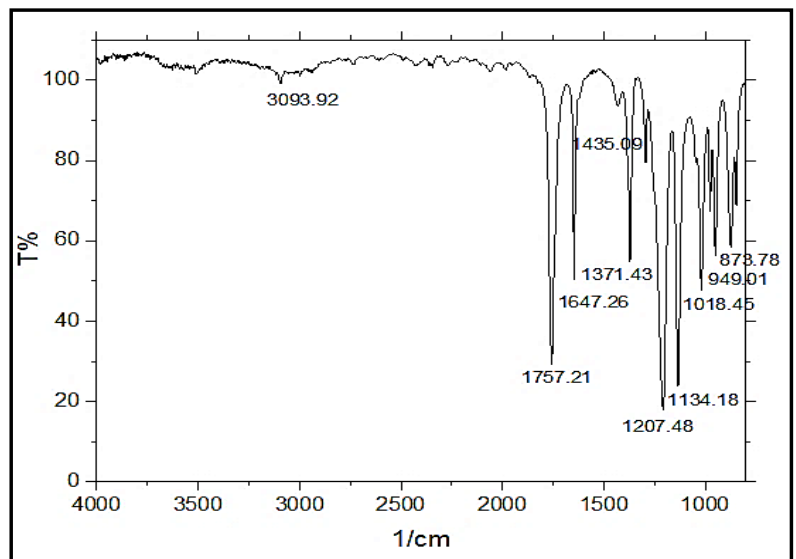

Fig.(3): FTIR spectrum of vinyl acetate. 
Table (1)

IR spectral data of poly(vinyl acetate)-g-Chitosan.

\begin{tabular}{|c|c|c|c|c|c|}
\hline $\begin{array}{c}v(\mathrm{~N}-\mathrm{H})+(\mathrm{O}-\mathrm{H}) \\
(\text { Hydrgen bonding }) \\
\left(\mathrm{cm}^{-1}\right)\end{array}$ & $\begin{array}{c}v\left(\mathrm{CH}_{2}\right) \\
\text { (asymmetric) } \\
\text { (symmetric) } \\
\left(\mathrm{cm}^{-1}\right)\end{array}$ & $\begin{array}{c}v(C=O) \\
\left(\mathrm{cm}^{-1}\right)\end{array}$ & $\begin{array}{c}\delta(O-H) \\
\delta(C-H) \text { wagging } \\
\left(\mathrm{cm}^{-1}\right)\end{array}$ & $\begin{array}{c}v(C-O-C) \\
\text { (Aymmetric) } \\
(\text { Symmetric) } \\
\left(\mathrm{cm}^{-1}\right)\end{array}$ & $\begin{array}{c}v(C-O) \text { grafted } \\
\text { chains } \\
\left(\mathrm{cm}^{-1}\right)\end{array}$ \\
\hline$(3120-3640)($ br. $)$ & $\begin{array}{l}(2949.66)(w) \\
(2831.37)(w)\end{array}$ & $(1732.13)(\mathrm{s})$ & $\begin{array}{c}(1408.08)(\mathrm{m}) \\
(1371.41)(\mathrm{s})\end{array}$ & $\begin{array}{l}(1082.11)(\mathrm{s}) \\
(1020.38)(\mathrm{s})\end{array}$ & $(1234.48)(\mathrm{m})$ \\
\hline
\end{tabular}

$\mathrm{v}=$ stretching, $\delta=$ bending, $\mathrm{s}=$ strong, $\mathrm{m}=$ medium, $\mathrm{w}=$ weak, br. $=$ broad
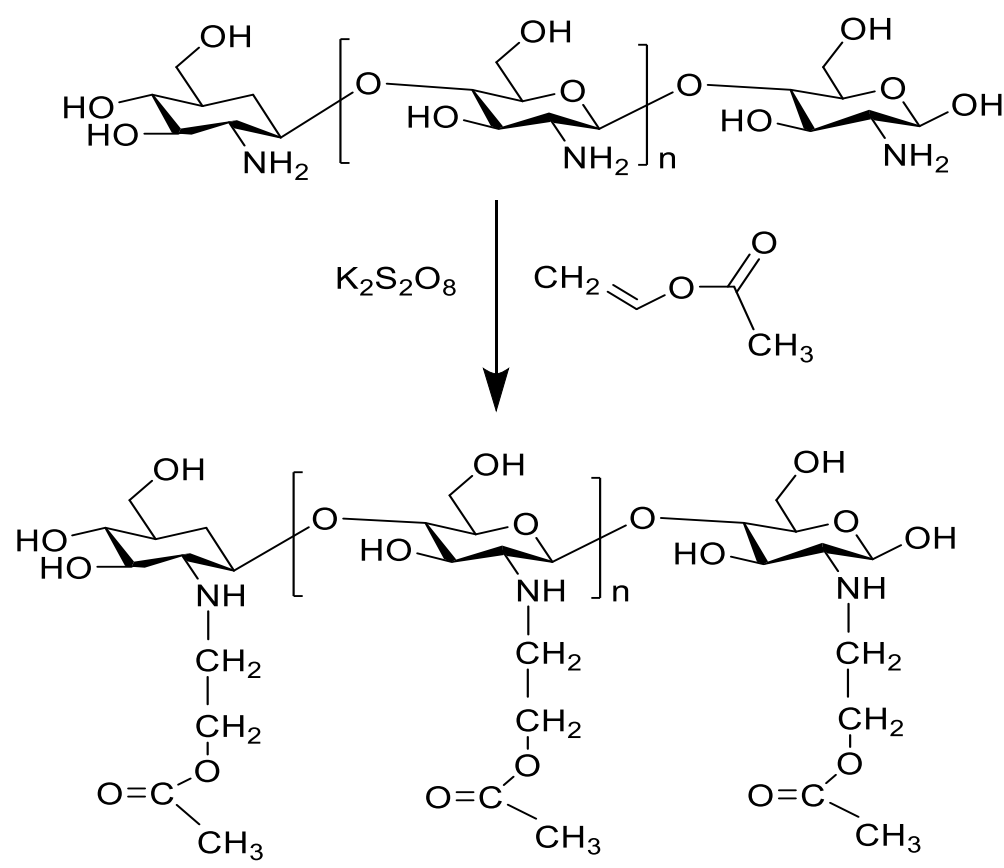

Scheme (1): General route of Chitosan grafted vinyl acetate.

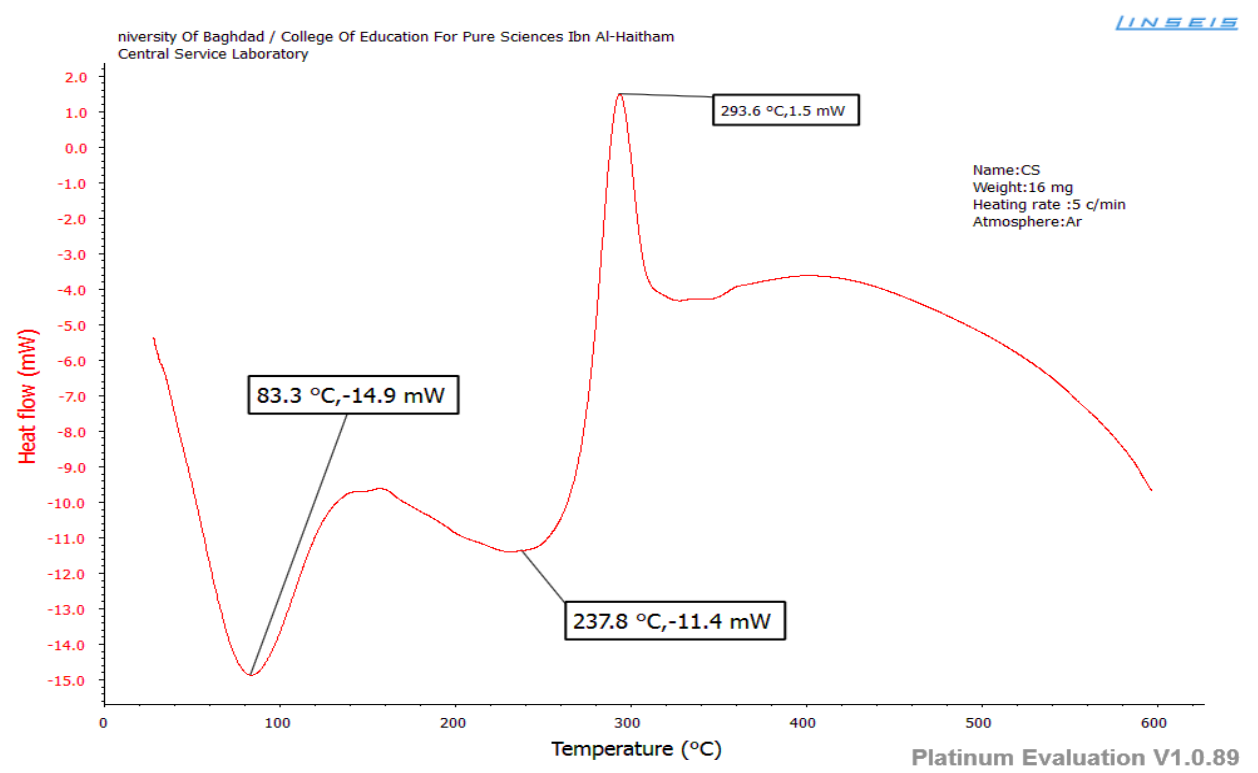

Fig.(4): DSC thermogram of pure Chitosan. 


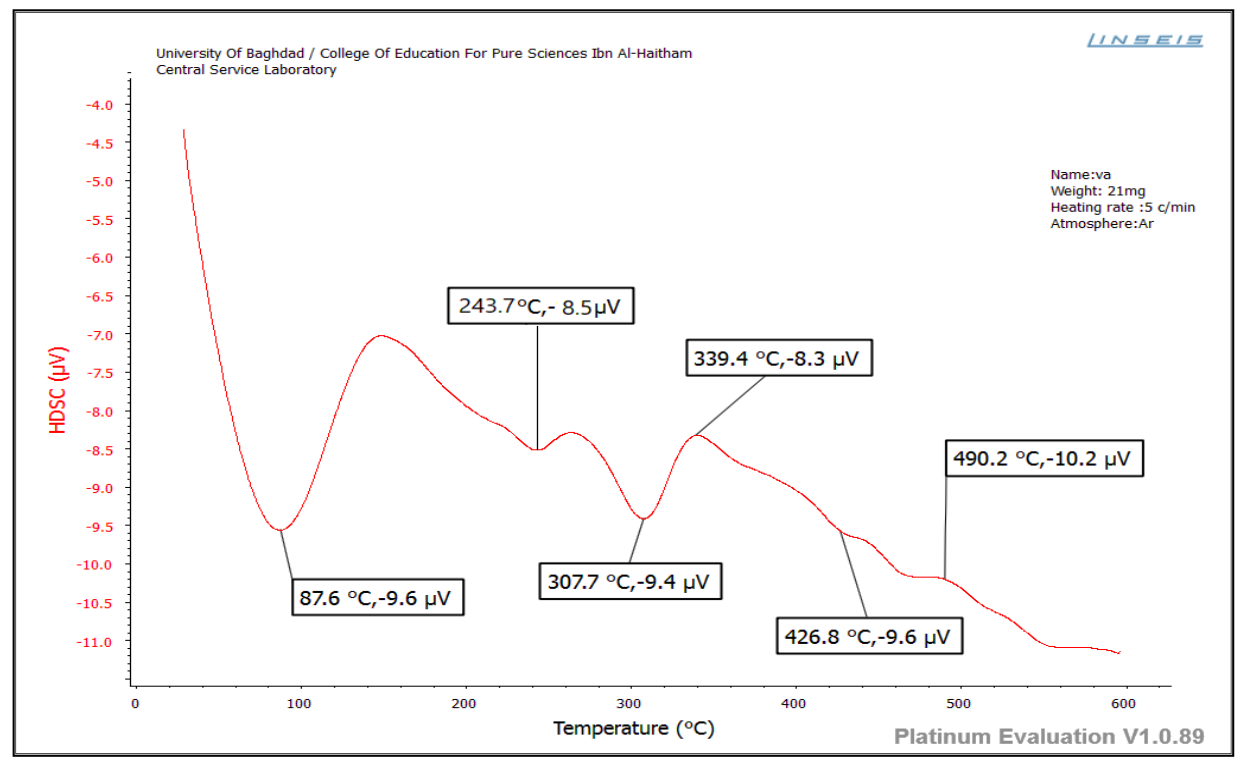

Fig.(5): DSC thermogram of poly(vinyl acetate)-g-Chitosan.

The DTG and TGA of pure chitosan, Fig.(6) exhibited two stages of different weight loss between $60^{\circ} \mathrm{C}$ and $597.062^{\circ} \mathrm{C}$. The first stage ranges from $60^{\circ} \mathrm{C}$ to $222.505^{\circ} \mathrm{C}$ with $10.53 \%$ weight loss of the adsorbed and bound water. The second stage of weight loss starts at $222.505^{\circ} \mathrm{C}$ and that keep on $597.062^{\circ} \mathrm{C}$ through $\mathrm{T}_{\max }=290^{\circ} \mathrm{C}$ with $65.355 \%$ of weight loss owing to the chitosan degradation [18].

While, DTG and TGA curve of poly vinyl acetate Fig.(7) showed four stages of diverse weight loss between among $60^{\circ} \mathrm{C}$ and $596.402^{\circ} \mathrm{C}$. The primary first stage ranges from $60^{\circ} \mathrm{C}$ to $199.787^{\circ} \mathrm{C}$ with $2.922 \%$ weight loss may related to the adsorbed also bound water loss.

The second stage of weight loss initiates at $199.787^{\circ} \mathrm{C}$ and $277.311^{\circ} \mathrm{C}$ with $14.57 \%$ of weight loss owing to ungrafted chitosan degradation. A $56.112 \%$ weight losses in the third stage between $277.311^{\circ} \mathrm{C}$ to $382.675^{\circ} \mathrm{C}$ through $\mathrm{T}_{\max }=316^{\circ} \mathrm{C}$ that contributes to the decomposition of chitosan grafted copolymer. So, it is evident that grafting vinyl acetate onto chitosan could enhance the stability of pure chitosan at higher temperature. There is $13.245 \%$ weight loss in the fourth stage from $382.675^{\circ} \mathrm{C}$ to $596.402^{\circ} \mathrm{C}$ that contributes to the decomposition of poly vinyl acetate chains grafted to chitosan.

\subsection{Calibration curve of $\mathrm{Cd}(\mathrm{II})$ ions}

A working calibration graft for $\mathrm{Cd}(\mathrm{II})$ ions quantitative analysis was create and valid by AAS at $\lambda 228.8 \mathrm{~nm}$ using standard solutions in the concentration range $0.2 \mathrm{mg} / \mathrm{L}$ to $0.8 \mathrm{mg} / \mathrm{L}$ in buffer $\mathrm{pH}=7$ aqueous solution, Fig.(8).

\subsection{Rate of $\mathrm{Cd}(\mathrm{II})$ ions adsorption as a function of equilibrium time}

The synthetic polymers have a maximum grafting percentage were chosen to study their ability for $\mathrm{Cd}$ (II) ions removals from aqueous samples. The interaction rate of $\mathrm{Cd}(\mathrm{II})$ ions with polymer was examined via batch method at several contact or equilibration time at $\mathrm{pH}=7$, Fig.(9). The results showed that a usual reliance on $\mathrm{Cd}$ (II) ions absorbed with contact time, also illustrate a fast equilibration rate within $76.65 \% \mathrm{Cd}(\mathrm{II})$ ions ions absorbed were attained after 5 min and get to a steady state within $1 \mathrm{hr}$. 
Ali Jasim Hammood

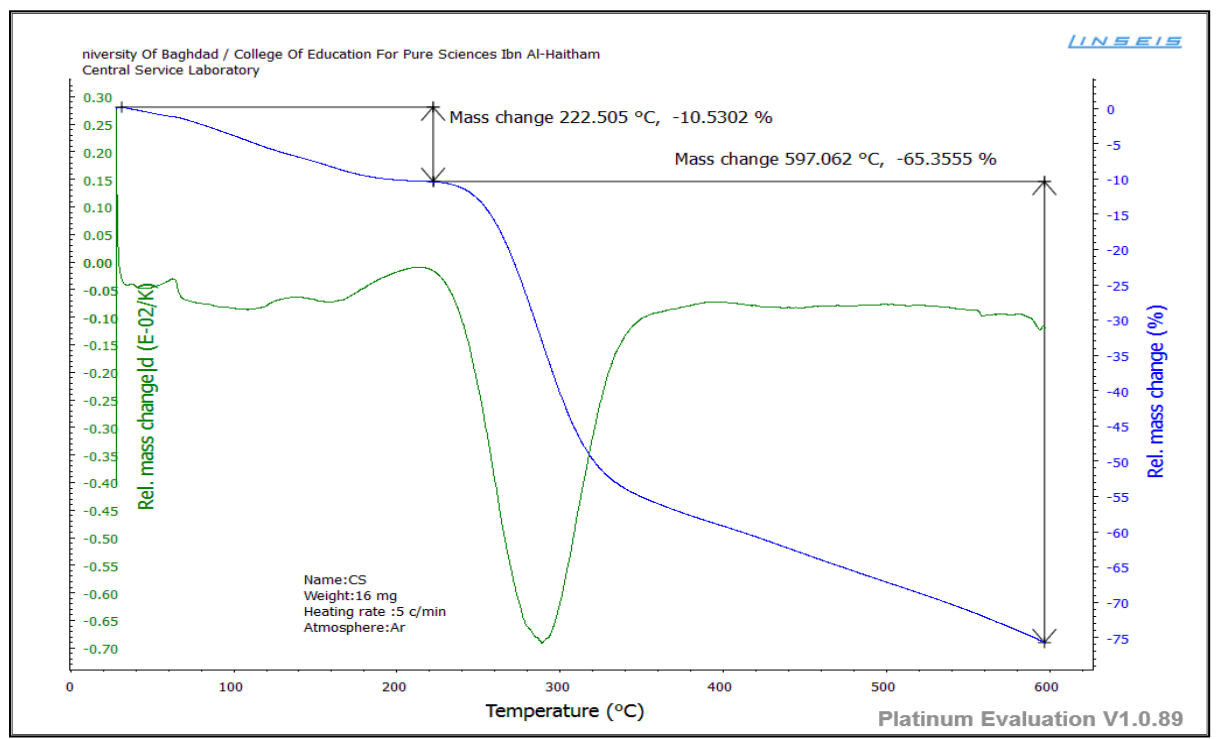

Fig.(6): DTG and TGA thermogram of pure Chitosan.

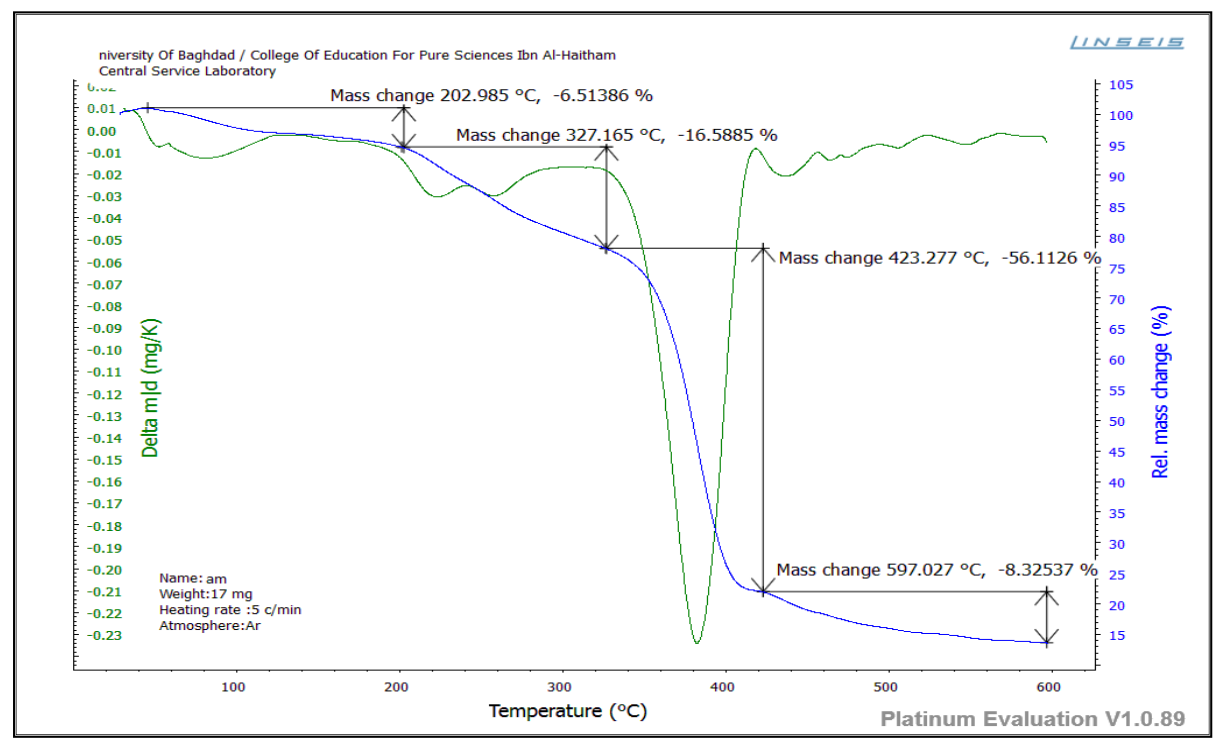

Fig.(7): DTG and TGA thermogram of poly(vinyl acetate)-g-Chitosan.

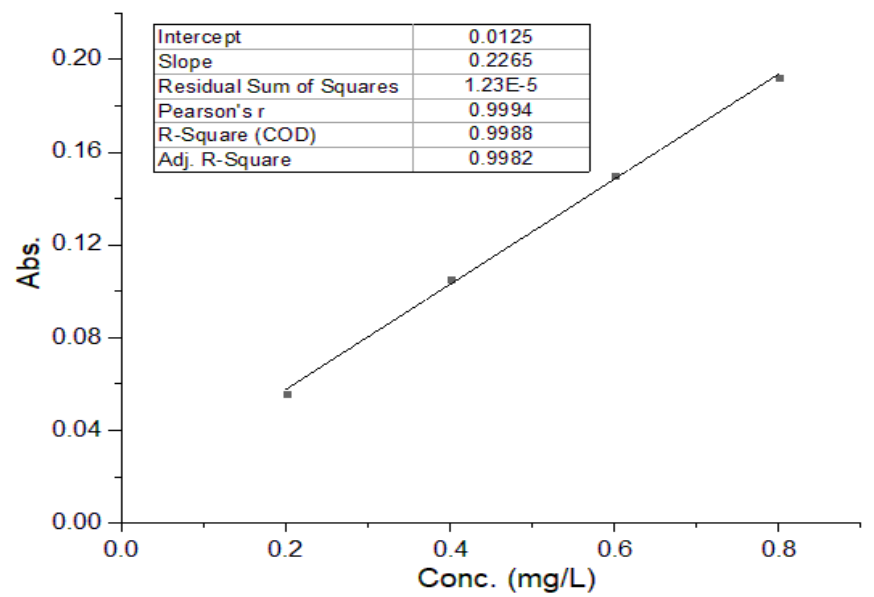

Fig.(8): Calibration curve for Cd(II) ions. 


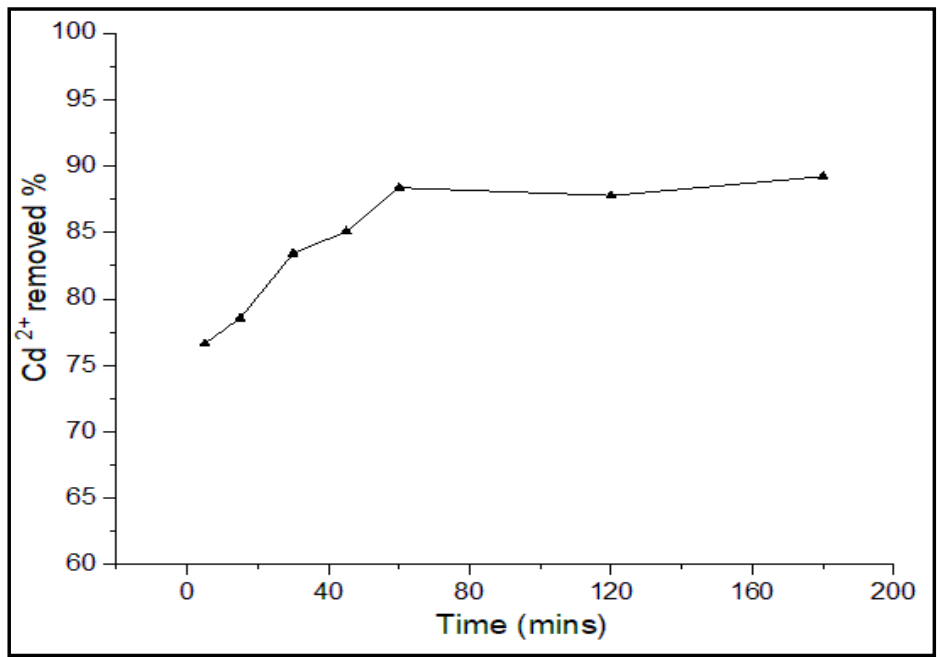

Fig.(9): Removal percentage of Cd(II) ions by the graft copolymer with time.

\subsection{Modeling isotherms}

Fig.(10) showed the adsorption isotherm of grafted copolymer, the isotherm graphs are like $\mathrm{L}$ type isotherm, this indicate that the adsorbate (Cd(II) ions) undergoes a highed sorption on to the adsorbent surface in very high concentration of $\mathrm{Cd}$ (II) ions.

Langmuir and Freundlich isotherms are the common adsorption models applied to explaining the experimental data [19]. Langmuir model suppose that the equilibrium was achieved after the formation of monolayer of the particles adsorbate formed on the adsorbent. The form of the linear Langmuir model was set as:

$\frac{C_{e}}{Q_{e}}=\frac{1}{b Q_{o}}+\frac{1}{Q_{o}} C_{e}$

Where $\mathrm{C}_{\mathrm{e}}$ is equilibrium adsorbate concentration, $Q_{0}$ is Langmuir constant associated to adsorption capacity while b: constant correlated to the affinity among the adsorbent also the adsorbate. The $\mathrm{Q}_{0}$ and b values were estimated by plotting $\mathrm{C}_{\mathrm{e}} / \mathrm{Q}_{\mathrm{e}}$ vs. $\mathrm{C}_{\mathrm{e}}$. Where $\mathrm{Q}_{\mathrm{e}}$ is the quantity of adsorbate uptake for each component adsorbent weight at equilibrium:

$\mathrm{Q}_{\mathrm{e}}=\frac{\left(C_{o}-C_{e}\right) V}{W}$

Where $\mathrm{C}_{0}$ : is the initial adsorbate concentration, $\mathrm{V}$ : the volume of solution, W weight of dry resin. The Langmuir isotherm characteristics are able to express as a dimensionless equilibrium parameter term, $\mathrm{R}_{\mathrm{L}}$ [20]:
$\mathrm{R}_{\mathrm{L}}=\frac{1}{1+b C_{o}}$

The value of $\left(R_{L}\right)$ indicates the type of the isotherm to be either favorable $\left(0<\mathrm{R}_{\mathrm{L}}<1\right)$, unfavorable $\left(\mathrm{R}_{\mathrm{L}}>1\right)$, linear $\left(\mathrm{R}_{\mathrm{L}}=1\right)$ or irreversible $\left(\mathrm{R}_{\mathrm{L}}=0\right)$. The practical Freundlich isotherm is a major significant multi-site adsorption isotherm for heterogeneous surfaces. It assumes an initial surface adsorption followed by the condensation effect resulting from extremely strong solute-solute interaction. The linear form of Freundlich model is as follows equation:

$$
\log Q_{e}=\log K_{F}+\left(\frac{1}{n}\right) \log C_{e}
$$

Where $\mathrm{K}_{\mathrm{F}}$ is Freundlich isotherm constant and correlated to maximum adsorption capacity. $\mathrm{n}$ is a Freundlich isotherm exponent constant which gives an indication of how favorable the adsorption process is [21]. The $\mathrm{K}_{\mathrm{F}}$ and $\mathrm{n}$ values were achieved by plotting $\mathrm{Log}$ $\mathrm{Q}_{\mathrm{e}}$ vs. $\log \mathrm{C}_{\mathrm{e}}$. Langmuir and Freundlich models were applied to fit the testing results, Figs.(11) and (12), which illustrate excellent fit of the testing results for Langmuir isotherm at $40^{\circ} \mathrm{C}$ and $50^{\circ} \mathrm{C}$ compared to Freundlich isotherm model and correlates well with both Langmuir and Freunlich equations at $30^{\circ} \mathrm{C}$. The results confirmed that the $\mathrm{Cd}(\mathrm{II})$ ions adsorption by grafted copolymer is distinguished by monolayer coated the $\mathrm{Cd}(\mathrm{II})$ ions on the external adsorbent surface of the synthetic polymer also the adsorption process had the same activation energy for all 
adsorbed particals. Additionally, the separation factor values $R_{L}$ found are ranged among $0<\mathrm{R}_{\mathrm{L}}<1$ which indicates a favorable Cd(II) ions adsorption on the polymers particles Fig.(13.) Thermodynamic function; $\Delta \mathrm{G}^{\mathrm{o}}, \Delta \mathrm{H}^{\mathrm{o}}$ and $\Delta S^{\circ}$ for the adsorption route was obtained using the following equation [22]:

$$
\operatorname{Ln} K_{d}=\frac{\Delta S}{R}-\frac{\Delta H}{R T} \text {. }
$$

Where $\mathrm{R}$ is the common gas constant, $\mathrm{T}$ : is the absolute temperature of the solution also $K_{d}$ is the distribution coefficient which be achieved through:

$K_{d}=\frac{C_{A E}}{C_{e}}$

Where $\mathrm{C}_{\mathrm{AE}}$ is the equilibrium amount adsorbing on the polymer also $\mathrm{C}_{\mathrm{e}}$ is the equilibrium concentration. A plot of $\ln \mathrm{K}_{\mathrm{d}}$ versus $1 / \mathrm{T}$. produced a direct line used for find the $\Delta \mathrm{H}^{\mathrm{o}}$ and $\Delta \mathrm{S}^{\mathrm{o}}$ from the slop also the intercept correspondingly. $\Delta \mathrm{G}^{\mathrm{o}}$ was obtained using the lower equation:

$\Delta G^{\circ}=-R T \operatorname{Ln} K_{d}$

The obtained values of standard enthalpy $\Delta \mathrm{H}^{\mathrm{o}}$ and standard entropy $\Delta \mathrm{S}^{\mathrm{o}}$ of graft copolymer are $96.87 \mathrm{~kJ} / \mathrm{mol}$ and $339.19 \mathrm{~J} / \mathrm{mol}$ $\mathrm{K}$ respectively. The positive $\Delta \mathrm{S}^{\mathrm{O}}$ values indicate the affinity of vinyl acetate grafted chitosan for adsorbates such as Cd(II) ions as a result of the increased randomness at the interface between the solid liquid phases.

The values of $\Delta \mathrm{G}^{\mathrm{o}}$ are $-5.11 \mathrm{KJ} / \mathrm{mol}$ at $30^{\circ} \mathrm{C},-11.13 \mathrm{KJ} / \mathrm{mol}$ at $40^{\circ} \mathrm{C}$ and $-11.78 \mathrm{KJ} / \mathrm{mol}$ at ${ }^{\circ} \mathrm{C}$ which demonstrate that the $\Delta \mathrm{G}^{\mathrm{o}}$ value decreases with the temperatures increases. This indicates the spontaneous nature and feasibility of the process [23].

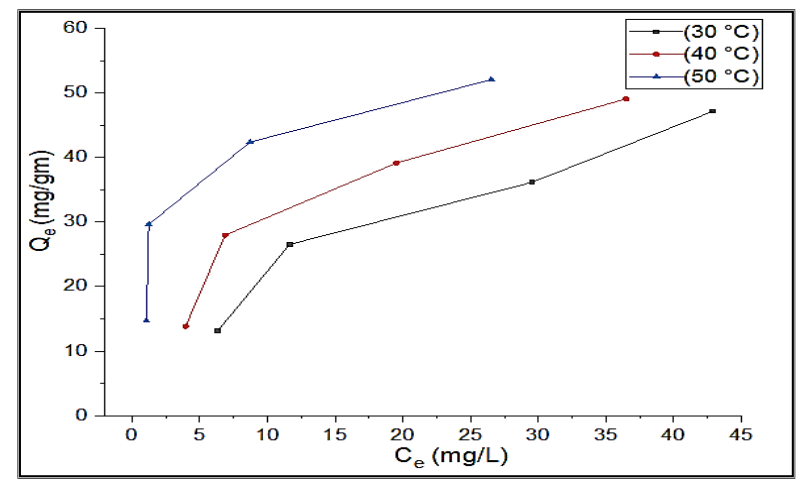

Fig.(10): $C d(I I)$ ions Adsorption isotherm by grafted copolymer at different temperatures.

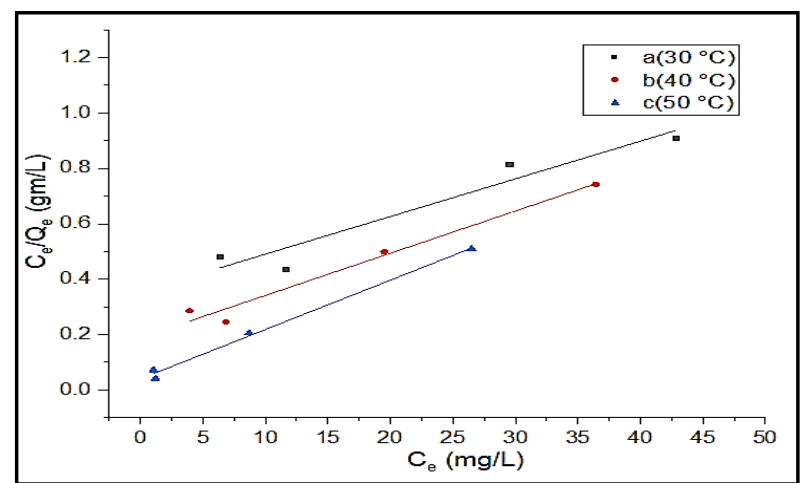

Fig.(11): Linearized Langmuir equation for Cd(II) ions uptake with grafted copolymer at different temperatures.

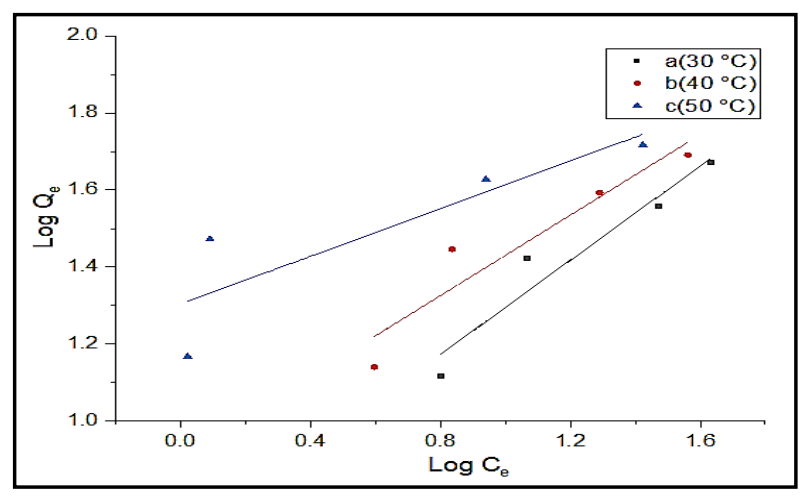

Fig.(12): Linearized Freunlich equation for Cd(II) ions uptake with grafted copolymer at different temperatures. 


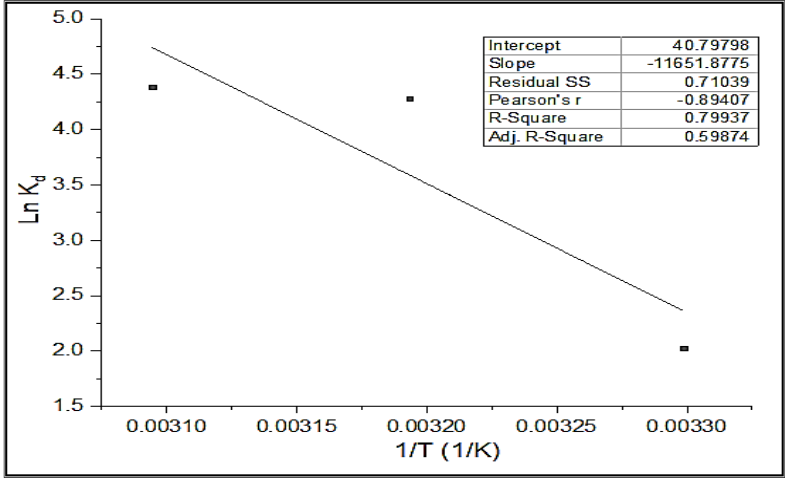

Fig.(13): Variation of thermodynamic parameters through temperature for the of Cd(II) ions adsorption on grafted copolymer.

\subsection{Kinetic study}

To illustrate the adsorption kinetics of graft copolymer, correlations of adsorbed amounts with time required through the investigation of special statistical expressions related to different models, which are first and second order equation [24].

\subsubsection{First order equation}

The first-order equation was commonly applied for the solute adsorption from liquid solution. The equation rearranged and linear it reads:

$$
\operatorname{Ln}\left(Q_{e}-Q_{t}\right)=\operatorname{Ln} Q_{e}-k_{1} t
$$

Where $K_{1}$ is the kinetic constant related to first-order adsorption, whereas $\mathrm{Q}_{\mathrm{e}}$ and $\mathrm{Q}_{\mathrm{t}}$ are the graft copolymer amounts be adsorbed at equilibrium also at $\mathrm{t}$ time. A graph of $\mathrm{Ln}$ $\left(\mathrm{Q}_{\mathrm{e}}-\mathrm{Q}_{\mathrm{t}}\right)$ versus $t$ produced a linear line.

\subsubsection{Second order equation}

The second-order equation expressed as:

$\frac{t}{Q_{t}}=\frac{1}{k_{2} Q_{e}^{2}}+\frac{1}{Q_{e}}$

Where $\mathrm{Q}_{\mathrm{t}}$ and $\mathrm{Q}_{\mathrm{e}}$ have the similar meaning as before, $\mathrm{k}_{2}$ is the related kinetic constant.

A draw of $t / q t$ against $t$ gives a slope line of $1 / Q_{e}$. The kinetic study of these adsorption isotherms showed that all have a good correlated through the second order equation according to their determination coefficient, Figs.(14) and (15).

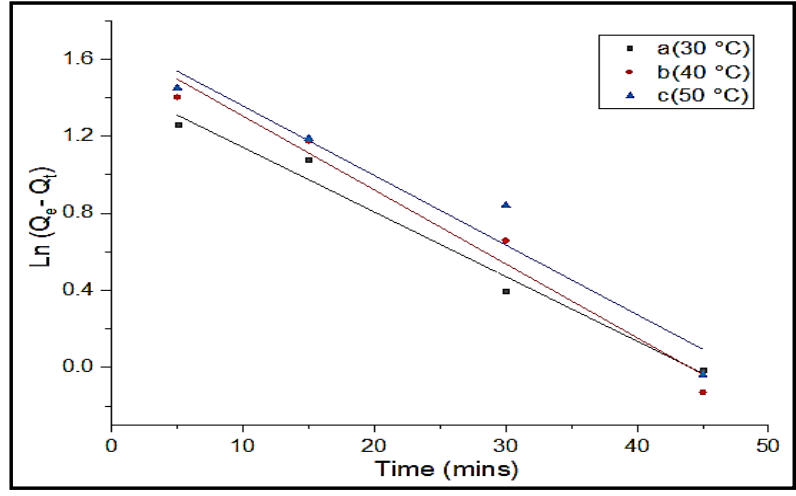

Fig.(14): Kinetic study for Cd(II) ions uptake on grafted copolymer by using of first order equation.

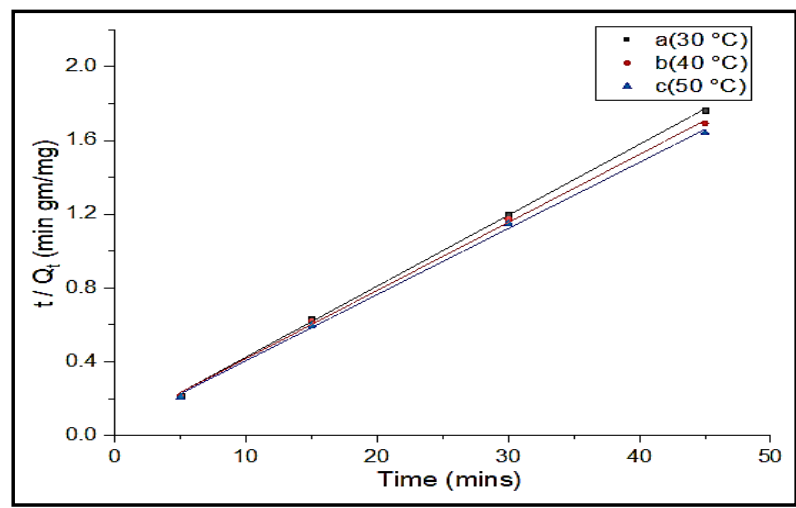

Fig.(15): Kinetic study for Cd(II) ions uptake on grafted copolymer by using of second order equation.

\section{Conclusions}

Poly(vinyl acetate)-g-chitosan was prepared by a copolymerization reaction between chitosan and vinyl acetate monomer. Grating percentage PG found to be increase with increasing of the monomer concentration PG polymer was used to study the sorption of $\mathrm{Cd}(\mathrm{II})$ ions at different concentrations, temperatures and $\mathrm{pH}=7$. In all cases, the adsorption kinetics could be very satisfactorily fitted by a second-order equation. All the adsorption isotherms could be very well adjusted by Langmuir's equation, but we found that the adsorption isotherm at $30^{\circ} \mathrm{C}$ was correlates well with both Langmuir and Freunlich equations. Results show that for the same equilibrium concentration on the loading capacity of the adsorbent increases with the increasing of temperature. It is confirmed the endothermic nature of $\mathrm{Cd}(\mathrm{II})$ ions adsorption onto grafted copolymer. The adsorption nature happened in monolayer with a very fast adsorption. 


\section{Acknowledgments}

Thanks and appreciation to Department of Chemistry, College of Science, Mustansiriah University. We grateful to Prof. Ahmed Jasim M. Al-Karawi, for his variety help in interpret the results. Also we express thanks to Assist. Prof. Dhafir T. Ajeel, for their kind help by carried out the thermal analyses of the polymers.

\section{References}

[1] Fares M. M., AL-Ta'ani B., Graft copolymerization onto chitosan: I. Grafting of ethylmethacrylate using ceric ammonium nitrate as an initiator, Acta Chim. Slov., 50(2), 275-285, 2003.

[2] Radhakumary C., Nair P. D., Mathew S., Nair C. P. R., Biopolymer composite of chitosan and methyl methacrylate for medical applications, Trends Biomater. Artif. Organs, 18(2), 117-124, 2005.

[3] Yu S., Zhao Y., Wu F., Zhang X., Lü W., Zhang H., Zhang Q., Nasal insulin delivery in the chitosan solution: in vitro and in vivo studies, Int. J. Pharm., 281 (1-2), 11-23, 2004.

[4] Tatjana R., Saulyte B., Aurelija L., Irina G., Asta Z., Gervydes D., Synthesis of chitosan-graft-poly(ethylene glycol) methyl ether methacrylate copolymer and its applications for immobilization of maltogenase, CHEMIJA, 18(2), 33-38, 2007.

[5] Takahashi T., Takayama K., Machida Y., Nagai T., Characteristics of polyion complexes of chitosan with sodium alginate and sodium polyacrylate, Int. J. Pharm., 61(1-2), 35-41, 1990.

[6] Kweon D. K., Kang D. W., Drug- release behavior of chitosan- g- poly (vinyl alcohol) copolymer matrix, J. Appl. Polym. Sci., 74(2), 458-464, 1999.

[7] Desbrieres J. and Guibal E., Chitosan for wastewater treatment, Polym. Int., 67(1), 7-14, 2018.

[8] Kurita K., Sannan T., Iwakura Y., Studies on chitin. VI. Binding of metal cations, J. Appl. Polym. Sci., 23(2), 511-515, 1979.

[9] Fadhil D. H., Al-Hussin A., Yousif E., Removal of Methylene Blue Dye from Water using Ecofriendly Waste Product (Eggshell) as an Adsorbent and Using the
Optimum Adsorption Conditions with Real Water Sample from Tigris River, Al-Nahrain J. Sci., 22(1), 9-14, 2019.

[10] Ali H. M., Zageer D., Alwash A. H., Synthesis of Activated Carbon from Eichhronia Crassipes Plant as Adsorbent for the Removal of Phenol from Aqueous Solution, Al-Nahrain J. Sci., 22(1), 46-54, 2019.

[11] Muzzarelli R., Biagini G., Pugnaloni A., Filippini O., Baldassarre V., Castaldini C., Rizzoli C., Reconstruction of parodontal tissue with chitosan, Biomaterials, 10(9), 598-603, 1989.

[12] Philippova O. E., Volkov E. V, Sitnikova N. L., Khokhlov A. R., Desbrieres J., Rinaudo M., Two types of hydrophobic aggregates in aqueous solutions of chitosan and its hydrophobic derivative, Biomacromolecules, 2(2), 483-490, 2001.

[13] Al-Karawi A. J. M., Al-Qaisi Z. H. J., Abdullah H. I., A. M. Al-Mokaram A., Al-Heetimi D. T. A., Synthesis, characterization of acrylamide grafted chitosan and its use in removal of copper (II) ions from water, Carbohydr. Polym., 83(2), 495-500, 2011.

[14] Zohuriaan-Mehr M. J., Advances in chitin and chitosan modification through graft copolymerization: a comprehensive review, Iran Polym J, 14 (3), 235-265, 2005.

[15] Yazdani- Pedram M., Retuert J., Quijada R., Hydrogels based on modified chitosan, 1. Synthesis and swelling behavior of poly (acrylic acid) grafted chitosan, Macromol. Chem. Phys., 201(9), 923-930, 2000.

[16] Sato H., Tsuge S., Ohtani H., K. Aoi, Takasu A., Okada M., Characterization of chitin-based polymer hybrids by temperature-programmed analytical pyrolysis techniques.1. Chitin-graft-poly (2methyl-2-oxazoline)/poly (vinyl chloride) blends, Macromolecules, 30(14), 40304037, 1997.

[17] Prashanth K. V. H., Tharanathan R. N., Studies on graft copolymerization of chitosan with synthetic monomers, Carbohydr. Polym., 54(3), 343-351, 2003. 
[18] Fares M. M., Al-Ta'ani B., Graft copolymerization onto chitosan: I. Grafting of ethylmethacrylate using ceric ammonium nitrate as an initiator, Acta Chim. Slov., 50(2), 275-285, 2003.

[19] Tan A. W., Hameed B. H., Ahmad A. L., Equilibrium and kinetic studies on basic dye adsorption by oil palm fibre activated carbon, Chem. Eng. J., 127(1-3), 111-119, 2007.

[20] Weber T. W., Chakravorti R. K., Pore and solid diffusion models for fixed- bed adsorbers, AIChE J., 20(2), 228-238, 1974.

[21] Hosseini M., Mertens S. F. L., Ghorbani M., Arshadi M. R., Asymmetrical Schiff bases as inhibitors of mild steel corrosion in sulphuric acid media, Mater. Chem. Phys., 78(3), 800-808, 2003.

[22] Ho Y.-S. and McKay G., Sorption of dye from aqueous solution by peat, Chem. Eng. J., 70(2), 115-124, 1998.

[23] Zalloum H. M., Al-Qodah Z., Mubarak M. S., Copper adsorption on chitosanderived Schiff bases, J. Macromol. Sci. Part A, 46(1), 46-57, 2008.

[24] Fierro V., Torné-Fernández V., Montané D., Celzard A., Adsorption of phenol onto activated carbons having different textural and surface properties, Microporous mesoporous Mater., 111(1-3), 276-284, 2008. 